10-16-2015

\title{
Faculty and Student Perceptions of a Physical Therapy Professional Behavior Mentoring Program
}

\author{
Ethel Frese \\ Saint Louis University, freseem@slu.edu \\ Cheryl Cavallo \\ Saint Louis University \\ Kelly Hawthorne \\ Saint Louis University \\ Ginge Kettenback \\ Saint Louis University \\ Barbara Yemm \\ Saint Louis University
}

Follow this and additional works at: https://nsuworks.nova.edu/ijahsp

Part of the Physical Therapy Commons, and the Physiotherapy Commons

\section{Recommended Citation}

Frese E, Cavallo C, Hawthorne K, Kettenback G, Yemm B. Faculty and Student Perceptions of a Physical Therapy Professional Behavior Mentoring Program. The Internet Journal of Allied Health Sciences and Practice. 2015 Oct 16;13(4), Article 10.

This Manuscript is brought to you for free and open access by the College of Health Care Sciences at NSUWorks. It has been accepted for inclusion in Internet Journal of Allied Health Sciences and Practice by an authorized editor of NSUWorks. For more information, please contact nsuworks@nova.edu. 


\title{
Faculty and Student Perceptions of a Physical Therapy Professional Behavior Mentoring Program
}

\begin{abstract}
Purpose: Mentoring is a process and a relationship between a novice and an expert that fosters intellectual, personal, and professional growth. The purposes and scope of this article are to describe 1) the structured professional development component of a comprehensive mentoring program for students in a physical therapy program; and 2) the perceptions of faculty and students regarding this mentoring program. Method: Faculty and students completed electronic questionnaires developed specifically for each group. Results: Return rate was $54.50 \%(\mathrm{~N}=286)$ for physical therapist students and $100 \%(\mathrm{~N}=18)$ for physical therapy faculty. Student positive ratings regarding the mentoring program exceeded $89.00 \%$. Additionally, $76.75 \%$ of the students reported seeking feedback and advice from their faculty mentor to make informed decisions. Students perceived their mentors to be committed to helping them achieve their personal/ professional goals (94.96\%). Faculty mentors reported that they enjoy being mentors $(94.12 \%)$, believe they have a responsibility to assist in the professional socialization of mentees $(100.00 \%)$, and that mentees benefitted from meeting with them regarding professional behavior issues (92.86\%). Conclusions: Faculty mentors and student mentees perceive that students benefit from mentoring regarding professional behavior issues and that the mentoring program is valuable and worth the time spent participating in it. We suggest that the process and documents developed by the Program in Physical Therapy may be used as a basis for critical dialogue within other academic units for the purpose of determining the desired professional behavior mentoring system for that particular academic entity.
\end{abstract}




\title{
IJAHSP \\ The Internet Journal of Allied Health Sciences and Practice
}

Dedicated to allied health professional practice and education

Vol. 13 No. 4 ISSN 1540-580X

\section{Faculty and Student Perceptions of a Physical Therapy Professional Behavior Mentoring Program}

\author{
Ethel Frese, PT, OPT, MHS, CCS 1 \\ Cheryl Cavallo, PT, PhD² \\ Kelly Hawthorne, PT, OPT, GCS 3 \\ Ginge Kettenback, $\mathrm{PT}, \mathrm{PhD}^{4}$ \\ Barbara Yemm, PT, OPT, OCS 5
}

1. Professor, Department of Physical Therapy and Athletic Training, Saint Louis University, St. Louis, MO

2. Assistant Professor, Department of Physical Therapy and Athletic Training, Saint Louis University, St. Louis, MO

3. Assistant Professor, Department of Physical Therapy and Athletic Training, Saint Louis University, St. Louis, MO

4. Associate Professor, Department of Physical Therapy and Athletic Training, Saint Louis University, St. Louis, MO

5. Assistant Professor, Department of Physical Therapy and Athletic Training, Saint Louis University, St. Louis, MO

United States

\begin{abstract}
Purpose: Mentoring is a process and a relationship between a novice and an expert that fosters intellectual, personal, and professional growth. The purposes and scope of this article are to describe 1) the structured professional development component of a comprehensive mentoring program for students in a physical therapy program; and 2) the perceptions of faculty and students regarding this mentoring program. Method: Faculty and students completed electronic questionnaires developed specifically for each group. Results: Return rate was $54.50 \%(\mathrm{~N}=286)$ for physical therapist students and $100 \%(\mathrm{~N}=18)$ for physical therapy faculty. Student positive ratings regarding the mentoring program exceeded $89.00 \%$. Additionally, $76.75 \%$ of the students reported seeking feedback and advice from their faculty mentor to make informed decisions. Students perceived their mentors to be committed to helping them achieve their personal/professional goals $(94.96 \%)$. Faculty mentors reported that they enjoy being mentors (94.12\%), believe they have a responsibility to assist in the professional socialization of mentees (100.00\%), and that mentees benefitted from meeting with them regarding professional behavior issues (92.86\%). Conclusions: Faculty mentors and student mentees perceive that students benefit from mentoring regarding professional behavior issues and that the mentoring program is valuable and worth the time spent participating in it. We suggest that the process and documents developed by the Program in Physical Therapy may be used as a basis for critical dialogue within other academic units for the purpose of determining the desired professional behavior mentoring system for that particular academic entity.
\end{abstract}

\section{INTRODUCTION}

The mentoring process has been described as a relationship between an expert in a particular field and a novice that fosters professional, personal, and intellectual growth. ${ }^{1-7}$ Mentorship is defined as a long-term, close, personal, and guiding relationship. ${ }^{8}$ Davis stated that the mentoring relationship should be dynamic, nurturing, and one that develops over time. ${ }^{9}$ The one-on-one mentoring relationship is particularly critical in academic settings with large class sizes where individual faculty/student interactions may be depersonalized and limited due to time constraints. ${ }^{7}$ The mentoring relationship can be a burden on faculty members, as it may be time intensive, thereby competing with other responsibilities. ${ }^{10}$

Many individuals have described an effective mentoring program as crucial to professional socialization. ${ }^{1,2,11,12}$ Ryan and Brewer state "this socialization process does not occur through direct teaching, but rather through a process of individual self-discovery and growth that can be facilitated in a mentoring relationship."7 Jacobi describes three components of the mentoring relationship: 1) emotional and psychological support; 2) direct assistance with career and professional development; and 3) role modeling. ${ }^{13}$

(c) The Internet Journal of Allied Health Sciences and Practice, 2015 
Essential elements of an effective mentor include knowledge of the profession and available resources for development, trustworthiness, willingness to help others, commitment to the mentoring relationship, accessibility, approachability, good communication skills, consistency, genuineness, respectfulness, and ability to give constructive criticism.1,2,5 Ultimately, the goals of a mentoring relationship are mentee independence, positive self-efficacy, and self-actualization., $5,7,14$

The Program in Physical Therapy at Saint Louis University, a private Jesuit University, is a freshman-admit program with a sixyear curriculum divided into a pre-professional phase (freshman, sophomore, junior) that encompasses undergraduate prerequisite courses and a professional phase (senior, professional year I and professional year II) that encompasses the physical therapy professional courses. The opportunity to begin mentoring students in the freshman year allows faculty members to engage students early in their personal/professional development. Mentoring continues for the duration of the curriculum and every effort is made to keep the same mentor/mentee match throughout all six years. Because professional academic advisors assume the curricular advising role at Saint Louis University, the mentoring program emphasizes academic and personal/professional development of the student rather than advising on curricular choices

Faculty who are full-time and who have been at the University for at least one year are assigned student mentees. Faculty mentors are not formally trained; however, informal mentor training among faculty occurs frequently. The program chair assigns mentees. The number of mentees assigned per faculty member ranges from ten to fifty based on faculty workload. The average number of mentees assigned to an individual faculty member in 2011-2012 was 29.

The goals of this comprehensive structured mentoring program are to 1) facilitate academic excellence; 2) facilitate development of personal and professional characteristics and values deemed important to the profession and Jesuit education; 3) provide a mechanism to ease transition from high school to college; 4) create a tracking mechanism that ensures the student has received academic and/ or personal/professional guidance from the faculty; 5) enhance professional socialization; 6) facilitate student retention; and 7) assist the student to become a reflective practitioner. ${ }^{15}$

Our comprehensive mentoring program addresses both academic performance and professional behavior. The purposes and scope of this article are to describe 1) the structured professional development component of a comprehensive mentoring program developed under the auspices of the Student Affairs Committee, Program in Physical Therapy, at Saint Louis University; and 2) the perceptions of faculty and students regarding this mentoring program. The academic component of our comprehensive mentoring program has been addressed previously. ${ }^{15}$

\section{Personal/Professional Behavior and Professional Socialization}

The personal/professional portion of the mentoring program is based on the work of May et al regarding generic abilities for physical therapists. Generic abilities are "identified abilities critically important to the practice of physical therapy."16 Based on student feedback and the work of Jette and Portney, the faculty condensed May's original ten generic abilities into six (Table 1). ${ }^{17}$ In addition, the modified generic abilities were aligned with the Five Dimensions of the Saint Louis University Experience and the Core Values of the American Physical Therapy Association (APTA) to establish an evolutionary step-wise progression in both personal/professional development and professional socialization (Table 1). The relationship between the generic abilities, Five Dimensions of Saint Louis University and the Core Values of the APTA is demonstrated in Table 1.

(c) The Internet Journal of Allied Health Sciences and Practice, 2015 
Table 1. Interaction of Generic Abilities, Core Values and the Five Dimensions

\begin{tabular}{|c|c|c|c|c|c|c|c|c|c|c|c|c|}
\hline \multirow[b]{2}{*}{ Generic Abilities } & \multicolumn{7}{|c|}{ Physical Therapy Core Values } & \multicolumn{5}{|c|}{$\begin{array}{l}\text { Five Dimensions of the Saint Louis University } \\
\text { Experience }\end{array}$} \\
\hline & 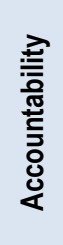 & 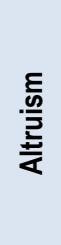 & 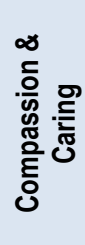 & 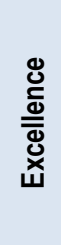 & 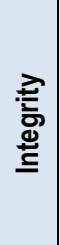 & 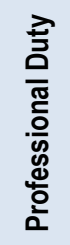 & 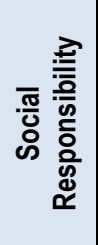 & 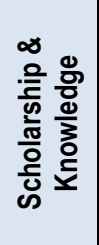 & 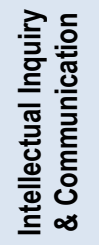 & 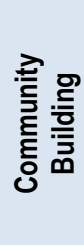 & 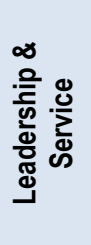 & 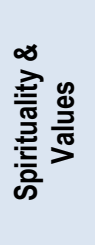 \\
\hline $\begin{array}{l}\text { Responsibility \& } \\
\text { Professionalism }\end{array}$ & $x$ & $x$ & $x$ & & $x$ & $x$ & & $x$ & & $x$ & $x$ & $x$ \\
\hline $\begin{array}{l}\text { Critical Thinking \& } \\
\text { Problem Solving }\end{array}$ & $x$ & & & $x$ & & $x$ & & & $x$ & & & \\
\hline $\begin{array}{l}\text { Commitment to } \\
\text { Learning \& Use of } \\
\text { Constructive } \\
\text { Feedback }\end{array}$ & $x$ & & & $x$ & & $x$ & & $x$ & $x$ & & & \\
\hline $\begin{array}{l}\text { Communication \& } \\
\text { Interpersonal Skills }\end{array}$ & $x$ & $x$ & $x$ & $x$ & $x$ & $x$ & $x$ & & $x$ & $x$ & $x$ & $x$ \\
\hline $\begin{array}{l}\text { Effective Use of Time } \\
\quad \text { \& Resources }\end{array}$ & $x$ & & & $\mathrm{x}$ & & $x$ & $x$ & & & & $x$ & \\
\hline Stress Management & $x$ & & $x$ & $x$ & & $x$ & & & & & & $x$ \\
\hline
\end{tabular}

Discussion of Generic Abilities begins in the pre-professional phase of the curriculum and continues throughout the professional phase (Table 2). The mentoring program has been revised twice, most recently to address the six-year clinical doctorate in physical therapy. Mentees are responsible for reflecting on their strengths and weaknesses within the context of the six generic abilities and completing a Generic Abilities Form (Appendix A). Mentees choose three of the six Generic Abilities to emphasize during the upcoming academic year. They write specific measureable goals and propose activities to achieve stated goals. The mentee's completed Generic Abilities Form is submitted to the mentor one week prior to the scheduled mentor/mentee meeting for review by the mentor.

Faculty mentors meet with individual students to discuss and give feedback regarding the student's proposed activities to meet specific goals as well as their self-identified timelines. The dialogue provides a springboard for rich mentor-mentee interaction. As the students approach their full time clinical experiences the Clinical Education Team assumes the responsibility of overseeing discussions of goal setting within the context of clinical performance and Generic Abilities.

Generic Abilities also provide a framework for faculty discussions with students who are demonstrating breaches of personal/professional behavior. Individual faculty members are encouraged to address students in a timely manner regarding unfavorable behavior following the Policy and Procedure Concerning Professional Behavior (Appendix B). The faculty member meets with the student and completes the Program's Professional Behavior Advisement Form (Appendix C). Levels of sanction include 1) No Sanction; 2) Professional Behavior Warning; 3) Professional Behavior Probation; 4) Dismissal from the Program. If the faculty member completing the form is not the student's mentor, the faculty member informs the mentor that a Professional Behavior Advisement Form has been completed. It is the mentor's responsibility to monitor the number of Professional Behavior Advisement Forms issued for their mentees. 
Table 2. Mentoring and Generic Abilities (GAS) Flow Sheet

\begin{tabular}{|c|c|c|c|c|c|c|}
\hline Semester & $\begin{array}{l}\text { Freshman } \\
\text { Year }\end{array}$ & $\begin{array}{l}\text { Sophomore } \\
\text { Year }\end{array}$ & $\begin{array}{l}\text { Junior } \\
\text { Year }\end{array}$ & $\begin{array}{l}\text { Senior } \\
\text { Year }\end{array}$ & $\begin{array}{l}\text { Professional } \\
\text { Year I }\end{array}$ & $\begin{array}{l}\text { Professional } \\
\text { Year II }\end{array}$ \\
\hline Fall & $\begin{array}{l}\text { Meet with faculty } \\
\text { mentor to discuss } \\
\text { transition to college } \\
\text { life: academic } \\
\text { skills, campus } \\
\text { resources; } \\
\text { student } \\
\text { organizations and } \\
\text { activities, } \\
\text { adjustment to dorm } \\
\text { life }\end{array}$ & $\begin{array}{l}\text { Meet individually } \\
\text { or in small } \\
\text { groups with } \\
\text { faculty mentor to } \\
\text { discuss PT } \\
\text { observation } \\
\text { experience } \\
\\
\text { Learn GAs in a } \\
\text { designated } \\
\text { class; practice } \\
\text { filling out GA } \\
\text { form; feedback } \\
\text { from instructor }\end{array}$ & $\begin{array}{l}\text { No formal } \\
\text { mentor } \\
\text { meetings; email } \\
\text { contact } \\
\text { between } \\
\text { student and } \\
\text { faculty mentor } \\
\\
\text { Students work } \\
\text { on activities to } \\
\text { achieve stated } \\
\text { GAs goals }\end{array}$ & $\begin{array}{l}\text { Following self- } \\
\text { reflection } \\
\text { completes GAs } \\
\text { form; meets with } \\
\text { faculty mentor } \\
\text { to discuss goals } \\
\text { and activities to } \\
\text { achieve stated } \\
\text { goals; modifies } \\
\text { form if } \\
\text { appropriate }\end{array}$ & $\begin{array}{l}\text { Following self- } \\
\text { reflection } \\
\text { completes GAs } \\
\text { form; meets with } \\
\text { faculty mentor to } \\
\text { discuss goals } \\
\text { and activities to } \\
\text { achieve stated } \\
\text { goals; modifies } \\
\text { form if } \\
\text { appropriate } \\
\text { Meets with } \\
\text { Clinical } \\
\text { Education Team } \\
\text { to discuss their } \\
\text { self -evaluation, } \\
\text { and set goals for } \\
\text { clinical } \\
\text { performance } \\
\text { based on the } \\
\text { concepts of } \\
\text { GAs; this is } \\
\text { clinical } \\
\text { education team } \\
\text { driven }\end{array}$ & $\begin{array}{l}\text { No formal GA } \\
\text { mentor meetings } \\
\text { Meets with } \\
\text { Clinical } \\
\text { Education Team } \\
\text { to discuss their } \\
\text { current self - } \\
\text { evaluation, and } \\
\text { set/revise goals } \\
\text { for clinical } \\
\text { performance } \\
\text { which } \\
\text { encompass } \\
\text { GAs; this is } \\
\text { student driven }\end{array}$ \\
\hline Spring & $\begin{array}{l}\text { Meet with faculty } \\
\text { mentor to discuss } \\
\text { satisfaction with } \\
\text { their academic } \\
\text { accomplishments; } \\
\text { campus activities, } \\
\text { future housing } \\
\text { plans; plans to } \\
\text { remedy } \\
\text { unsuccessful } \\
\text { transitions }\end{array}$ & $\begin{array}{l}\text { Following self- } \\
\text { reflection } \\
\text { completes GAs } \\
\text { form; meets with } \\
\text { faculty mentor to } \\
\text { discuss goals } \\
\text { and activities to } \\
\text { achieve stated } \\
\text { goals; modifies } \\
\text { form if } \\
\text { appropriate }\end{array}$ & $\begin{array}{l}\text { Following self- } \\
\text { reflection } \\
\text { completes GAs } \\
\text { form; meets } \\
\text { with faculty } \\
\text { mentor to } \\
\text { discuss goals } \\
\text { and activities to } \\
\text { achieve stated } \\
\text { goals; modifies } \\
\text { form if } \\
\text { appropriate }\end{array}$ & $\begin{array}{l}\text { Small group } \\
\text { meeting with } \\
\text { mentor to } \\
\text { discuss their } \\
\text { transition into } \\
\text { the professional } \\
\text { phase of the PT } \\
\text { Program, } \\
\text { current clinical } \\
\text { experience and } \\
\text { progress in the } \\
\text { Senior Year } \\
\text { Students work } \\
\text { on activities to } \\
\text { achieve stated } \\
\text { GAs goals } \\
\text { Meet in small } \\
\text { groups with } \\
\text { clinical } \\
\text { education team } \\
\text { to discuss early } \\
\text { part time clinical } \\
\text { experience }\end{array}$ & $\begin{array}{l}\text { No formal GA } \\
\text { mentor meetings } \\
\text { Meets with } \\
\text { Clinical } \\
\text { Education Team } \\
\text { to discuss their } \\
\text { current self - } \\
\text { evaluation, and } \\
\text { set/revise goals } \\
\text { for clinical } \\
\text { performance } \\
\text { which } \\
\text { encompass } \\
\text { GAs; this is } \\
\text { student } \\
\text { driven/clinical } \\
\text { education team } \\
\text { driven }\end{array}$ & $\begin{array}{l}\text { No formal GA } \\
\text { mentor meetings } \\
\text { Continues with } \\
\text { Clinical } \\
\text { Education Team }\end{array}$ \\
\hline
\end{tabular}

The faculty member can choose the "No Sanction" category if in his/her judgment a Professional Behavior Warning is not warranted. The faculty member uses the professional behavior advisement process to inform the student concerning unacceptable behaviors and to discuss mechanisms for change. A pattern of unacceptable behaviors will result in a Professional Behavior Warning. 
A Professional Behavior Warning is a sanction given to a student who demonstrates multiple breaches of professional behavior or a serious single action. A Professional Behavior Warning can be issued by any faculty member. If a faculty mentor receives multiple notifications of unacceptable student behaviors, the faculty mentor will issue a Professional Behavior Warning if one has not been issued previously.

If a student receives a second Professional Behavior Warning or one warning of a nature which warrants probation in the professional judgment of the student's faculty mentor, the Program Assistant Director, and the Program Director, the student will be placed on Professional Behavior Probation. Professional Behavior Probation entails the completion of certain specified activities and/or the ability to demonstrate appropriate change in the observed behaviors as designated in a written contract and determined by recommendations from concerned faculty. The student will be removed from Professional Behavior Probation after completing one full enrolled semester free of professional behavior breaches. A student who receives a Professional Behavior Warning while on Professional Behavior Probation is subject to dismissal.

All faculty/mentor discussions regarding professional behavior concerns are documented. The student is asked to respond in writing to the faculty's concerns and sign the Professional Behavior Advisement Form. An electronic copy is posted by the faculty member on the Program's secure web site and a hard copy is placed in the student's file until graduation. All forms are destroyed upon student graduation.

The faculty member notifies the student's mentor that a meeting has occurred. The faculty mentor is responsible for monitoring the number of Professional Behavior Advisement Forms issued to the student and notifying the Program Chair when appropriate. A student may be dismissed from the Program if in the judgment of the student's faculty mentor, the assistant Program Director, and the Program Director behaviors have not improved or the student has committed a single egregious act. The student has the right to appeal dismissal from the Physical Therapy Program.

\section{METHODS}

\section{Questionnaire}

In order to assess faculty and students' perceptions of the comprehensive mentoring program, the Student Affairs Committee developed a faculty questionnaire and a student questionnaire. A 4-point Likert-type scale was used that included strongly disagree, disagree, agree, and strongly agree. A not applicable choice was provided and spaces for comments also were included. Face and content validity were established via a panel of experts in health care education and student focus groups. Construct validity was achieved through careful consideration of the current literature related to professional behavior mentoring programs in the health sciences. The Institutional Review Board at Saint Louis University approved the study.

\section{Participants}

The questionnaires were administered electronically to 18 faculty members and 524 physical therapist students. A reminder to complete the questionnaire was sent to both faculty and students via email one week after the initial distribution. Return of the questionnaire indicated consent of the participants.

\section{RESULTS}

Student response rate was $54.50 \%(\mathrm{~N}=286)$. Response rates in the tables vary since not all respondents answered every question or chose the not applicable option. There was minimal difference in the response rate between the pre-professional phase cohort (53.82\%) and the professional phase cohort (55.85\%) (Table3). For purposes of data analysis, the response categories were collapsed into agree or disagree. Student positive ratings regarding the mentoring program exceeded $89.00 \%$. Additionally, $76.75 \%$ of the students reported seeking feedback and advice from their faculty mentor to make informed decisions (Table 4).

Table 3. Overall Questionnaire Response by Class

\begin{tabular}{|c|l|c|c|}
\hline Phase of Program & \multicolumn{1}{|c|}{ Academic Year } & Percent of Total Respondents & Response Rate \\
\hline \multirow{3}{*}{ Pre-Professional } & Freshman $(\mathrm{N}=108)$ & $20.98 \%(\mathrm{~N}=60)$ & $55.55 \%(60 / 108)$ \\
\cline { 2 - 4 } & Sophomore $(\mathrm{N}=111)$ & $19.93 \%(\mathrm{~N}=57)$ & $51.35 \%(57 / 111)$ \\
\cline { 2 - 4 } & Junior $(\mathrm{N}=82)$ & $15.73 \%(\mathrm{~N}=45)$ & $54.88 \%(45 / 82)$ \\
\hline \multirow{3}{*}{ Professional } & Senior $(\mathrm{N}=76)$ & $17.13 \%(\mathrm{~N}=49)$ & $64.47 \%(49 / 76)$ \\
\cline { 2 - 4 } & Professional Year I $(\mathrm{N}=79)$ & $14.68 \%(\mathrm{~N}=42)$ & $53.16 \%(42 / 79)$ \\
\cline { 2 - 4 } & Professional Year II $(\mathrm{N}=67)$ & $11.54 \%(\mathrm{~N}=33)$ & $49.25 \%(33 / 67)$ \\
\hline
\end{tabular}

(c) The Internet Journal of Allied Health Sciences and Practice, 2015 
Table 4. Student Ratings of Mentoring Program

\begin{tabular}{|c|c|c|c|}
\hline Item & $\begin{array}{l}\text { Overall Strongly } \\
\text { Agree/ Agree } \\
\text { Response }\end{array}$ & $\begin{array}{l}\text { Pre-Professional } \\
\text { Phase Strongly } \\
\text { Agree/ Agree } \\
\text { Response }\end{array}$ & $\begin{array}{c}\text { Professional } \\
\text { Phase } \\
\text { Strongly Agree/ Agree } \\
\text { Response }\end{array}$ \\
\hline $\begin{array}{l}\text { 1. As a result of my mentoring experiences, I } \\
\text { believe the mentoring program is valuable. }\end{array}$ & $\begin{array}{c}94.46 \% \\
(256 / 271)\end{array}$ & $\begin{array}{c}94.00 \% \\
(141 / 150)\end{array}$ & $\begin{array}{c}95.04 \% \\
(115 / 121)\end{array}$ \\
\hline $\begin{array}{l}\text { 2. As a result of my mentoring experiences, I } \\
\text { communicate with my faculty mentor when } \\
\text { necessary. }\end{array}$ & $\begin{array}{l}96.31 \% \\
(261 / 271)\end{array}$ & $\begin{array}{c}97.33 \% \\
(146 / 150)\end{array}$ & $\begin{array}{c}95.04 \% \\
(115 / 121)\end{array}$ \\
\hline $\begin{array}{l}\text { 3. As a result of my mentoring experiences, I } \\
\text { benefit from the relationship with my faculty } \\
\text { mentor }\end{array}$ & $\begin{array}{c}89.30 \% \\
(242 / 271)\end{array}$ & $\begin{array}{c}92.00 \% \\
(138 / 150)\end{array}$ & $\begin{array}{c}85.95 \% \\
(104 / 121)\end{array}$ \\
\hline $\begin{array}{l}\text { 4. As a result of my mentoring experiences, I } \\
\text { believe my faculty mentor and I have a positive } \\
\text { relationship }\end{array}$ & $\begin{array}{c}98.52 \% \\
(267 / 271)\end{array}$ & $\begin{array}{c}98.67 \% \\
(148 / 150)\end{array}$ & $\begin{array}{c}98.35 \% \\
(119 / 121)\end{array}$ \\
\hline $\begin{array}{l}\text { 5. As a result of my mentoring experiences, I seek } \\
\text { feedback and advice from my faculty mentor to } \\
\text { make informed decisions }\end{array}$ & $\begin{array}{c}76.75 \% \\
(208 / 271)\end{array}$ & $\begin{array}{c}79.33 \% \\
(119 / 150)\end{array}$ & $\begin{array}{c}73.55 \% \\
(89 / 121)\end{array}$ \\
\hline $\begin{array}{l}\text { 6. As a result of my mentoring experiences, I } \\
\text { believe the mentoring process is worth the time I } \\
\text { spent participating in it }\end{array}$ & $\begin{array}{c}92.25 \% \\
(250 / 271)\end{array}$ & $\begin{array}{c}92.67 \% \\
(139 / 150)\end{array}$ & $\begin{array}{c}91.74 \% \\
(111 / 121)\end{array}$ \\
\hline $\begin{array}{l}\text { 7. As a result of my mentoring experiences, I have } \\
\text { a better understanding of my role and } \\
\text { responsibilities as a future physical therapist }\end{array}$ & $\begin{array}{c}95.20 \% \\
(258 / 271)\end{array}$ & $\begin{array}{c}94.67 \% \\
(142 / 150)\end{array}$ & $\begin{array}{c}95.87 \% \\
(116 / 121)\end{array}$ \\
\hline
\end{tabular}

The majority of students viewed the Generic Abilities process positively (Table 5). Results demonstrate that the professional behavior expectations of the Program (91.09\%) and the profession of physical therapy (90.10\%) are made clear to students through the Generic Abilities self-assessment process. Students indicated that completing the Generic Abilities process helped them to improve their ability to self-assess (84.16\%) and to grow personally/professionally $(75.25 \%)$. A smaller majority of the students indicated that completing the Generic Abilities process was worth the time participating in it $(55.94 \%)$ or helped them change their behavior (62.38\%) (Table 5).

Table 5. Student Perceptions of Generic Abilities Self -Assessment (GASA)

\begin{tabular}{|c|c|c|c|}
\hline Item & $\begin{array}{l}\text { Overall Strongly } \\
\text { Agree/ Agree } \\
\text { Response }\end{array}$ & $\begin{array}{c}\text { Pre-Professional } \\
\text { Phase Strongly } \\
\text { Agree/ Agree } \\
\text { Response }\end{array}$ & $\begin{array}{c}\text { Professional } \\
\text { Phase } \\
\text { Strongly Agree/ Agree } \\
\text { Response }\end{array}$ \\
\hline $\begin{array}{l}\text { 1. Completing the GASA process helps me grow } \\
\text { personally/professionally }\end{array}$ & $\begin{array}{c}75.25 \% \\
(152 / 202)\end{array}$ & $\begin{array}{l}87.80 \% \\
(72 / 82)\end{array}$ & $\begin{array}{l}66.67 \% \\
(80 / 120) \\
\end{array}$ \\
\hline $\begin{array}{l}\text { 2. Completing the GASA process helps improve my } \\
\text { ability to self-assess }\end{array}$ & $\begin{array}{c}84.16 \% \\
(170 / 202)\end{array}$ & $\begin{array}{l}91.46 \% \\
(75 / 82)\end{array}$ & $\begin{array}{l}79.17 \% \\
(95 / 120)\end{array}$ \\
\hline $\begin{array}{l}\text { 3. Completing the GASA process helps me change } \\
\text { my behavior }\end{array}$ & $\begin{array}{c}62.38 \% \\
(126 / 202) \\
\end{array}$ & $\begin{array}{l}78.05 \% \\
(64 / 82) \\
\end{array}$ & $\begin{array}{l}51.67 \% \\
(62 / 120) \\
\end{array}$ \\
\hline $\begin{array}{l}\text { 4. Completing the GASA process is worth the time } \\
\text { spent participating in it }\end{array}$ & $\begin{array}{c}55.94 \% \\
(113 / 202) \\
\end{array}$ & $\begin{array}{l}74.39 \% \\
(61 / 82) \\
\end{array}$ & $\begin{array}{l}43.33 \% \\
(52 / 120)\end{array}$ \\
\hline $\begin{array}{l}\text { 5. Completing the GASA process helps me know the } \\
\text { expectations of the Program in Physical Therapy }\end{array}$ & $\begin{array}{c}91.09 \% \\
(184 / 202) \\
\end{array}$ & $\begin{array}{l}97.56 \% \\
(80 / 82)\end{array}$ & $\begin{array}{c}86.67 \% \\
(104 / 120) \\
\end{array}$ \\
\hline $\begin{array}{l}\text { Completing the GASA process helps me know the } \\
\text { expectations of the Physical Therapy profession }\end{array}$ & $\begin{array}{c}90.10 \% \\
(182 / 202)\end{array}$ & $\begin{array}{l}97.56 \% \\
(80 / 82)\end{array}$ & $\begin{array}{c}85.00 \% \\
(102 / 120)\end{array}$ \\
\hline
\end{tabular}

Table 6 illustrates the positive perceptions that students reported regarding their faculty mentors. Students perceived their mentors to be committed to helping them achieve their personal/professional goals (94.96\%), trustworthy (93.09\%), positive role models (94.91\%), and knowledgeable of the physical therapy profession (96.03\%). Students reported that faculty mentors appear to enjoy working with students $(95.68 \%)$, treat them with respect $(95.68 \%)$, and demonstrate genuine concern for their well-being $(94.12 \%)$. Students 
perceived faculty mentors as having good communication skills $(93.88 \%)$, expressing interest in the students as unique individuals $(91.70 \%)$, and giving constructive criticism (93.38\%). Of the 286 respondents, only 4 students $(1.46 \%)$ indicated they were contacted by their mentor regarding professional behavior issues. Three out of the 4 students $(75.00 \%)$ reported they appreciated and benefited from the contact (Table 7).

Table 6. Student Perceptions of Faculty Mentor

\begin{tabular}{|c|c|c|c|}
\hline Item & $\begin{array}{c}\text { Overall Strongly } \\
\text { Agree/ Agree } \\
\text { Response }\end{array}$ & $\begin{array}{c}\text { Pre-Professional } \\
\text { Phase Strongly } \\
\text { Agree/ Agree } \\
\text { Response }\end{array}$ & $\begin{array}{c}\text { Professional } \\
\text { Phase } \\
\text { Strongly Agree/ Agree } \\
\text { Response } \\
\end{array}$ \\
\hline $\begin{array}{l}\text { 1. Faculty mentor is committed to helping me achieve } \\
\text { my personal and professional goals }\end{array}$ & $\begin{array}{c}94.96 \% \\
(264 / 278)\end{array}$ & $\begin{array}{c}96.79 \% \\
(151 / 156)\end{array}$ & $\begin{array}{c}92.62 \% \\
(113 / 122) \\
\end{array}$ \\
\hline 2. Faculty mentor is someone whom I trust & $\begin{array}{c}93.09 \% \\
(256 / 275) \\
\end{array}$ & $\begin{array}{c}96.75 \% \\
(149 / 154) \\
\end{array}$ & $\begin{array}{c}88.43 \% \\
(107 / 121) \\
\end{array}$ \\
\hline 3. Faculty mentor is a positive role model & $\begin{array}{c}94.91 \% \\
(261 / 275)\end{array}$ & $\begin{array}{c}96.75 \% \\
(149 / 154)\end{array}$ & $\begin{array}{c}92.56 \% \\
(112 / 121)\end{array}$ \\
\hline 4. Faculty mentor is available in a timely manner & $\begin{array}{c}91.58 \% \\
(250 / 273) \\
\end{array}$ & $\begin{array}{c}93.46 \% \\
(143 / 153) \\
\end{array}$ & $\begin{array}{c}89.17 \% \\
(107 / 120) \\
\end{array}$ \\
\hline $\begin{array}{l}\text { 5. Faculty mentor appears to enjoy working with } \\
\text { students }\end{array}$ & $\begin{array}{c}95.68 \% \\
(266 / 278)\end{array}$ & $\begin{array}{c}96.79 \% \\
(151 / 156)\end{array}$ & $\begin{array}{c}94.26 \% \\
(115 / 122) \\
\end{array}$ \\
\hline $\begin{array}{ll}\text { 6. Faculty mentor allows sufficient time to discuss } \\
\text { issues or problems }\end{array}$ & $\begin{array}{c}94.53 \% \\
(259 / 274) \\
\end{array}$ & $\begin{array}{c}96.71 \% \\
(147 / 152) \\
\end{array}$ & $\begin{array}{c}91.80 \% \\
(112 / 122) \\
\end{array}$ \\
\hline $\begin{array}{l}\text { 7. Faculty mentor expresses interest in me as a } \\
\text { unique individual }\end{array}$ & $\begin{array}{c}91.70 \% \\
(254 / 277) \\
\end{array}$ & $\begin{array}{c}95.51 \% \\
(149 / 156)\end{array}$ & $\begin{array}{c}86.78 \% \\
(105 / 121)\end{array}$ \\
\hline $\begin{array}{l}\text { 8. Faculty mentor demonstrates genuine concern for } \\
\text { my wellbeing }\end{array}$ & $\begin{array}{c}94.12 \% \\
(256 / 272) \\
\end{array}$ & $\begin{array}{c}96.71 \% \\
(147 / 152) \\
\end{array}$ & $\begin{array}{c}90.83 \% \\
(109 / 120) \\
\end{array}$ \\
\hline $\begin{array}{l}\text { 9. Faculty mentor helps foster my relationships with } \\
\text { PT faculty and staff }\end{array}$ & $\begin{array}{c}85.45 \% \\
(229 / 268) \\
\end{array}$ & $\begin{array}{c}90.54 \% \\
(134 / 148) \\
\end{array}$ & $\begin{array}{l}79.17 \% \\
(95 / 120) \\
\end{array}$ \\
\hline 10. Faculty mentor has good communication skills & $\begin{array}{c}93.88 \% \\
(261 / 278)\end{array}$ & $\begin{array}{c}96.79 \% \\
(151 / 156)\end{array}$ & $\begin{array}{c}90.16 \% \\
(110 / 122)\end{array}$ \\
\hline 11. Faculty mentor treats me with respect & $\begin{array}{c}95.68 \% \\
(266 / 278) \\
\end{array}$ & $\begin{array}{c}96.79 \% \\
(151 / 156) \\
\end{array}$ & $\begin{array}{c}94.26 \% \\
(115 / 122) \\
\end{array}$ \\
\hline 12. Faculty mentor gives constructive criticism & $\begin{array}{c}93.38 \% \\
(254 / 272) \\
\end{array}$ & $\begin{array}{c}94.04 \% \\
(142 / 151) \\
\end{array}$ & $\begin{array}{c}92.56 \% \\
(112 / 121) \\
\end{array}$ \\
\hline $\begin{array}{l}\text { 13. Faculty mentor has good knowledge of the } \\
\text { physical therapy profession }\end{array}$ & $\begin{array}{c}96.03 \% \\
(266 / 277)\end{array}$ & $\begin{array}{c}96.77 \% \\
(150 / 155)\end{array}$ & $\begin{array}{c}95.08 \% \\
(116 / 122)\end{array}$ \\
\hline
\end{tabular}

Table 7. Perceptions of Students Contacted By Their Mentor Regarding Professional Behavior Issues.

\begin{tabular}{|c|c|c|c|}
\hline Item & $\begin{array}{l}\text { Overall Strongly } \\
\text { Agree/ Agree } \\
\text { Response }\end{array}$ & $\begin{array}{c}\text { Pre-Professional Phase } \\
\text { Strongly Agree/ Agree } \\
\text { Response }\end{array}$ & $\begin{array}{c}\text { Professional } \\
\text { Phase } \\
\text { Strongly Agree/ Agree } \\
\text { Response }\end{array}$ \\
\hline 1. I appreciated contact from my mentor & $\begin{array}{c}75.00 \% \\
(3 / 4)\end{array}$ & $\begin{array}{c}100.00 \% \\
(2 / 2)\end{array}$ & $\begin{array}{c}50.00 \% \\
(1 / 2)\end{array}$ \\
\hline 2. I benefited from the contact from my mentor. & $\begin{array}{c}75.00 \% \\
(3 / 4)\end{array}$ & $\begin{array}{c}100.00 \% \\
(2 / 2)\end{array}$ & $\begin{array}{c}50.00 \% \\
(1 / 2)\end{array}$ \\
\hline $\begin{array}{l}\text { 3. The contact and discussion helped me change } \\
\text { my behavior }\end{array}$ & $\begin{array}{c}50.00 \% \\
(2 / 4)\end{array}$ & $\begin{array}{c}50.00 \% \\
(1 / 2)\end{array}$ & $\begin{array}{c}50.00 \% \\
(1 / 2)\end{array}$ \\
\hline
\end{tabular}

Faculty response rate was $100.00 \%(\mathrm{~N}=18)$. Faculty mentors reported that they enjoy being mentors $(94.12 \%)$ and believe they have a responsibility to assist in the professional socialization of mentees $(100.00 \%)$. Mentors believed mentees benefited from meeting with them regarding professional behavior issues (92.86\%), Generic Abilities (72.22\%), and non-academic issues $(88.23 \%)$. They indicated the mentoring program helped mentees grow personally/professionally (94.44\%), helped mentees with professional socialization $(88.89 \%)$, improved their ability to self-assess $(100.00 \%)$, and helped students to know the expectations of the Program and the physical therapy profession (94.12\%). Mentors perceived the mentoring program overall to be valuable $(94.12 \%)$ and worth the time participating in it $(82.35 \%)$. All mentors reported the sharing of professional and personal experiences with their mentees, and $94.44 \%$ believed the mentoring program helped foster a relationship with their mentees (Table 8). 
Table 8. Faculty Perceptions of Mentor Contact Regarding Professional Behavior Issues Item Overall Strongly Agree/ Agree Response

\begin{tabular}{|c|c|}
\hline 1. & $\begin{array}{l}\text { I think my mentees benefited from meeting with me regarding } \\
\text { professional behavior issues. }\end{array}$ \\
\hline 2. & $\begin{array}{l}\text { I think my mentees benefited from meeting with me regarding } \\
\text { generic abilities. }\end{array}$ \\
\hline
\end{tabular}

3. I think my mentees benefited from meeting with me regarding non-academic issues.

4. The mentoring program helps mentees grow personally/ professionally.

5. The mentoring program helps mentees with professional socialization.

6. The mentoring program improves mentees' ability to selfassess.

7. The mentoring program helps foster my relationship with my mentees.

8. Overall, I enjoy being a mentor.

9. The mentoring program [overall] is valuable.

10. The mentoring program [overall] is worth the time I spend participating in it.

Overall Strongly Agree/
$92.86 \%$
$(13 / 14)$

$72.22 \%$

(13/18)

$88.23 \%$

$(15 / 17)$

$94.44 \%$

(17/18)

$88.89 \%$

(16/18)

$100.00 \%$

$(18 / 18)$

$94.44 \%$

$(17 / 18)$

$94.12 \%$

$(16 / 17)$

$94.12 \%$

$(16 / 17)$

$82.35 \%$

$(14 / 17)$

11. Overall, I have shared professional and personal experiences with my mentee.

$100.00 \%$

$(17 / 17)$

12. I think my mentees believe the mentoring program is valuable.

13. Overall, I believe that I have a responsibility to assist in the professional socialization of mentees.

$88.23 \%$

$(15 / 17)$

$100.00 \%$

$(17 / 17)$

14. Overall, I think the mentoring program helps my mentees know the expectations of the Program and profession.

$94.12 \%$

$(16 / 17)$

\section{DISCUSSION}

A major role of the faculty mentor is to establish a relationship with the mentee that enhances the student's personal/professional development. ${ }^{1-7}$ Our results support this role in that students overwhelmingly perceived that they benefited from meeting and establishing a relationship with their faculty mentor. One student wrote, "I like having the chance to build a relationship with a faculty member. It is helpful, both personally and professionally, to have a member of the faculty know you on a level that goes beyond our academic records. My mentor understands my personality and, therefore, is better suited to help me self-assess and create goals for myself." Another student commented "I like that as I get further into the program, I already have an established relationship with one of the professors, and it makes the transition to the professional phase years a lot smoother. I also like that my mentor takes a personal interest in my life as a student and as a person -- she is always wanting to hear other things I am participating in other than studying or going to class, which is nice that she appreciates that we all need a break."

The results of our study support that our mentoring program fulfills the three components of the mentoring relationship as described by Jacobi. ${ }^{13}$ Most of the respondents believed that faculty mentors were genuinely concerned with their well-being. One student stated, "Even though it is required, going to mentor meeting(s) is something I would do even if it was not. My mentor not only gives me advice about the PT profession, but also helps me with personal issues such as stress management and selfexpectations. She makes me feel more confident in myself as a future physical therapist, a student, and a person overall." Mentors also are perceived as an important student resource for career and professional development as illustrated by this quote: "[l] Get to talk about PT and PT choices/issues along the PT path with someone who has a lot of knowledge and has worked with students in similar situations." Greater than $94.00 \%$ of the respondents supported this perception. A high percentage of the students perceived that faculty serve as positive role models. One student commented they liked "having a member of the faculty available as a role model and to keep students on track in the professional and academic portion of the PT program." 
Student perceptions of their faculty mentors as illustrated in Table 6 support that faculty mentors demonstrate the essential elements of faculty mentoring including, but not limited to, knowledge of the profession, trustworthiness, willingness to help others, and commitment to the mentoring relationship. Students perceived that faculty mentors enjoy working with students, and this is supported by faculty responses indicating that $94.00 \%$ of faculty members enjoy being a mentor. This positive perception of faculty mentors by students is further supported by the comment, "The mentors are all very interested in the students, both professionally and individually. I love how helpful and out reaching the mentors are."

Students perceived the Generic Abilities process to have its pros and cons. Students agreed that the process helps them grow personally and professionally, improves their ability to self-assess, changes their behavior, and increases their knowledge of the expectations of our Program and our profession. Pre-professional phase students reported that the Generic Abilities process was worth the time spent participating in it and they reported changing their behavior to a greater degree than the professional phase students. One reason a smaller percentage of the professional hase students might not have found the Generic Abilities process to be worth the time spent participating in it was because the Generic Abilities Form for this phase emphasized clinical behavior more than classroom behavior, and the students had limited clinical experience at the time they were completing the Form. Further, Professional phase students may have already made any necessary changes subsequent to prior conversations regarding behavioral expectations and need for change with their mentors during the pre-professional phase Generic Abilities meetings. The logical consequence is that a smaller percentage of this group would report a behavior change. Nonetheless, more that $50.00 \%$ of the professional phase students reported a change in their behavior.

Faculty perceptions as illustrated in Table 8 were overwhelmingly positive regarding the benefits of the professional behavior mentoring program. All faculty reported that they share personal and professional experiences with their mentees, believe they have a responsibility to assist in the professional socialization of mentees, and believe the mentoring program improves mentees' abilities to self-assess. While $92.86 \%$ of faculty members think mentees benefitted from meeting regarding professional behavior issues, only $72.22 \%$ reported mentees benefitted from meeting regarding Generic Abilities. Although greater than $94.00 \%$ reported the mentoring program as valuable and that they enjoy being a mentor, only $82.35 \%$ responded that it was worth the time spent participating in it. One faculty member commented, "Our mentoring program has many benefits, many of which are highlighted in the questions asked. I am challenged to 'keep up with the paperwork.' While I know its value, I prefer to spend my time talking to the students and find the paperwork necessary to complete too time consuming."

Table 9 (next page) illustrates the commonalities between student and faculty perceptions regarding the mentoring program. In some instances the wording was similar, but not exactly the same. Although the Generic Abilities process is a large piece of the comprehensive mentoring program, it is only one component of mentoring.

Our results support that both students and faculty perceive the Generic Abilities process positively. Both faculty and students believe students benefited from meeting with their faculty mentors regarding professional behavior issues. 
Table 9. Comparison of Student and Faculty Perceptions

\begin{tabular}{|c|c|c|c|}
\hline Student Item & $\begin{array}{l}\text { Overall Student Strongly } \\
\text { Agree/Agree Response }\end{array}$ & Faculty Item & $\begin{array}{l}\text { Overall Faculty Strongly } \\
\text { Agree/ Agree Response }\end{array}$ \\
\hline \multirow{2}{*}{$\begin{array}{l}\text { I believe the mentoring program } \\
\text { is valuable. }\end{array}$} & \multirow{2}{*}{$\begin{array}{c}94.46 \% \\
(256 / 271)\end{array}$} & $\begin{array}{l}\text { The mentoring program } \\
\text { [overall] is valuable. }\end{array}$ & $\begin{array}{l}94.12 \% \\
(16 / 17) \\
\end{array}$ \\
\hline & & $\begin{array}{l}\text { I think my mentees believe the } \\
\text { mentoring program is valuable. }\end{array}$ & $\begin{array}{l}88.23 \% \\
(15 / 17)\end{array}$ \\
\hline $\begin{array}{l}\text { I believe the mentoring process } \\
\text { is worth the time I spent } \\
\text { participating in it }\end{array}$ & $\begin{array}{c}92.25 \% \\
(250 / 271)\end{array}$ & $\begin{array}{l}\text { The mentoring program } \\
\text { [overall] is worth the time I } \\
\text { spend participating in it. }\end{array}$ & $\begin{array}{l}82.35 \% \\
(14 / 17)\end{array}$ \\
\hline $\begin{array}{l}\text { Completing the GASA process } \\
\text { helps me grow } \\
\text { personally/professionally }\end{array}$ & $\begin{array}{c}75.25 \% \\
(152 / 202)\end{array}$ & $\begin{array}{l}\text { The mentoring program helps } \\
\text { mentees grow personally/ } \\
\text { professionally. }\end{array}$ & $\begin{array}{l}94.44 \% \\
(17 / 18)\end{array}$ \\
\hline $\begin{array}{l}\text { Completing the GASA process } \\
\text { helps me know the } \\
\text { expectations of the Program in } \\
\text { Physical Therapy }\end{array}$ & $\begin{array}{c}91.09 \% \\
(184 / 202)\end{array}$ & \multirow{2}{*}{$\begin{array}{l}\text { Overall, I think the mentoring } \\
\text { program helps my mentees } \\
\text { know the expectations of the } \\
\text { Program and profession. }\end{array}$} & \multirow{2}{*}{$\begin{array}{l}94.12 \% \\
(16 / 17)\end{array}$} \\
\hline $\begin{array}{l}\text { Completing the GASA process } \\
\text { helps me know the } \\
\text { expectations of the Physical } \\
\text { Therapy profession }\end{array}$ & $\begin{array}{c}90.10 \% \\
(182 / 202)\end{array}$ & & \\
\hline $\begin{array}{l}\text { Faculty mentor appears to } \\
\text { enjoy working with students }\end{array}$ & $\begin{array}{c}95.68 \% \\
(266 / 278) \\
\end{array}$ & Overall, I enjoy being a mentor. & $\begin{array}{l}94.12 \% \\
(16 / 17) \\
\end{array}$ \\
\hline $\begin{array}{l}\text { As a result of my mentoring } \\
\text { experiences, I believe my } \\
\text { faculty mentor and I have a } \\
\text { positive relationship }\end{array}$ & $\begin{array}{c}98.52 \% \\
(267 / 271)\end{array}$ & $\begin{array}{l}\text { The mentoring program helps } \\
\text { foster my relationship with my } \\
\text { mentees. }\end{array}$ & $\begin{array}{l}94.44 \% \\
(17 / 18)\end{array}$ \\
\hline
\end{tabular}

\section{CONCLUSION}

Faculty mentors and student mentees perceive that students benefit from mentoring regarding professional behavior issues and that the mentoring program is valuable and worth the time spent participating in it. This article describes one academic unit with a unique program structure, and the results may not be generalizable to other health professional programs. We suggest that the process and documents developed by the Program in Physical Therapy may be used as a basis for critical dialogue within other academic units for the purpose of determining the desired professional behavior mentoring system for that particular academic entity.

\section{REFERENCES}

1. Cahill HA. A qualitative analysis of student nurses' experiences of mentorship. J Adv Nurs. 1996 Oct;24(4):791-9. [PMID 8894897]

2. Davis DS. Teaching professionalism: a survey of physical therapy educators. J Allied Health. 2009 Summer;38(2):7480. [PMID 19623788]

3. Goran SF. Mentorship as a teaching strategy. Crit Care Nurs Clin North Am. 2001 Mar;13(1):119-29. [PMID 11863134]

4. Lamport MA. Student-faculty informal interaction and the effect on college student outcomes: a review of the literature. Adolesc. 1993 Winter;28(112):971-90. [PMID 8266849]

5. Pitney WA, Ehlers GG. A grounded theory study of the mentoring process involved with undergraduate athletic training students. J Athl Train. 2004 Dec;39(4):344-51. [PMID 15592607]

6. Rogers JC. Mentoring for career achievement and advancement. Am J Occup Ther. 1986 Feb;40(2):79-82. [PMID 3953748]

7. Ryan D, Brewer K. Mentorship and professional role development in undergraduate nursing education. Nurse Educ. 1997 Nov-Dec;22(6):20-4. [PMID 9416084]

8. Kinsey DC. Mentorship and influence in nursing. Nurs Manag. 1990 May;21(5):45-6. [PMID 2336217]

9. $\quad$ Davis AJ. You need someone older and wiser. Am J Nurs. 1984 Oct;84(10):1290-1. [PMID 6567455]

10. Garmel GM. Mentoring medical students in academic emergency medicine. Acad Emerg Med. 2004 Dec;11(12):13517. [PMID 15576528] 
11. Bohannon RW. Mentorship: a relationship important to professional development. A special communication. Phys Ther. 1985 Jun;65(6):920-3. [PMID 4001172]

12. Sabari JS. Professional socialization: implications for occupational therapy education. Am J Occup Ther. 1985 Feb;39(2):96-102. [PMID 3976829]

13. Jacobi M. Mentoring and undergraduate academic success: A literature review. Rev Educ Res. 1991;61:505-32.

14. Larose S, Bernier A, Soucy N. Attachment as a moderator of the effect of security in mentoring on subsequent perceptions of mentoring and relationship quality with college teachers. J Soc Pers Relat. 2005;22:399-415.

15. Frese E CC, Hawthone K, Kettenbach G, Wilder E, Yemm B. Faculty and student perceptions of a physical therapy academic mentoring program. The Internet Journal of Allied Health Sciences and Practice. 2014;12(4).

16. May WW, Morgan BJ, Lemke JC, Karst GM, Stone HL. Model for ability-based assessment in physical therapy education. Journal of Physical Therapy Education. 1995;9:3-6.

17. Jette JU, Portney LG. Construct validation of a model for professional behavior in physical therapist students. Phys Ther. 2003;83(5):432-3. [PMID 12718709] 


\section{Appendix A}

Saint Louis University Program in Physical Therapy Generic Abilities

Student Name: $\square$ Sophomore $\square$ Junior $\square$ Senior Prof. Yr. I Prof. Yr. II

Faculty Mentor: Meeting Date:

Instructions

1. Reflect on your professional behavior using the Generic Abilities grid. You must self-assess on each of the six Generic Abilities. Mark each descriptor that you consistently perform. All descriptors in the Pre-Professional phase must be achieved by the end of the Pre-Professional phase (first three years of the program). All descriptors in the Professional phase must be achieved by the end of the Professional phase of the curriculum (last three years of the program).

a. $\quad$ Sophomore and Junior students must self-assess using the Pre-Professional Phase column.

b. $\quad$ Seniors and new transfer students with a BS/BA degree must self-assess using both the Pre-Professional Phase and Professional Phase columns.

c. Students in Professional Years I and II must self-assess using the Professional Phase column.

2. After self-assessment, choose three Generic Abilities on which to focus. Write one goal for each of the chosen Generic Abilities. For each goal, write three realistic activities to achieve the goal.

a. Goal = the descriptors/behaviors within a Generic Ability that you would like to improve, including the time frame to achieve the goal e.g., by the end of the semester; by the time you next meet with your mentor

b. $\quad$ Activity $=$ a plan of action (something you do) to achieve a goal

3. Prior to your yearly meeting with your mentor, you must reassess your previous goals and activity statements. Be prepared to discuss your reassessment with your mentor.

4. Contact your mentor by e-mail at least one month in advance with several days/times you are available to meet.

5. One week prior to the meeting, you must send an electronic copy of the Generic Abilities grid to your mentor and to the Student/Professional Development instructor. Your mentor will notify you by e-mail upon receipt of the form. You must also bring a copy of the completed form to your meeting.

Reviewed by

(Student signature)

(Date)

Reviewed by

(Faculty signature)

(Date)

\section{REFERENCES:}

Jette DU \& Portney LD (2003). Construct validation of a model for professional behavior in physical therapists students, Physical Therapy, 83, 432-443. May WW, Morgan BJ, Lemke JC, Karst GM, Stone HL (1995). Model for ability-based assessment in physical therapy education, Journal of Physical Therapy Education, 9, 3-6. May WW, Straker G, Foord-May, L. "Appendix D: Academic Setting Self-Assessment Form," Opportunity Favors the Prepared. May and Associates Consulting, p. 261-283.

Revised: 09/22/2006, 07/2007 


\begin{tabular}{|c|c|c|c|}
\hline Generic Ability & $\begin{array}{l}\text { Pre-Professional Phase } \\
\text { Descriptors }\end{array}$ & $\begin{array}{l}\text { Professional Phase } \\
\text { Descriptors }\end{array}$ & Plan for Development \\
\hline $\begin{array}{l}\text { 1. Responsibility \& } \\
\text { Professionalism } \\
\text { The ability to fulfill } \\
\text { commitments, be } \\
\text { accountable for actions } \\
\text { and outcomes, exhibit } \\
\text { appropriate professional } \\
\text { conduct, and represent the } \\
\text { profession effectively. }\end{array}$ & $\begin{array}{l}\square \text { Demonstrates } \\
\text { dependability } \\
\square \text { Demonstrates } \\
\text { punctuality } \\
\square \text { Completes } \\
\text { projects/assignments } \\
\text { without prompting } \\
\square \text { Demonstrates } \\
\text { participation in small } \\
\text { groups } \\
\square \text { Recognizes own limits } \\
\square \text { Fulfills commitments } \\
\square \text { Accepts responsibility } \\
\text { for actions and outcomes } \\
\square \text { Abides by academic } \\
\text { policies and procedures } \\
\square \text { Acts honestly and with } \\
\text { integrity in all academic } \\
\text { situations } \\
\square \text { Demonstrates } \\
\text { compassion, courage and } \\
\text { respect for all individuals } \\
\square \text { Acts on moral } \\
\text { commitment } \\
\square \text { Recognizes the role of } \\
\text { physical therapy in health } \\
\text { care } \\
\square \text { Identifies qualities of } \\
\text { positive professional role } \\
\text { models }\end{array}$ & $\begin{array}{l}\square \text { Provides safe and secure } \\
\text { environment in academic and } \\
\text { clinical settings } \\
\square \text { Works collaboratively in a } \\
\text { group } \\
\square \text { Projects professional image } \\
\text { through attire appropriate for } \\
\text { the situation } \\
\square \text { Abides by clinical policies } \\
\text { and procedures } \\
\square \text { Acts honestly and with } \\
\text { integrity in all clinical situations } \\
\square \text { Treats patients/clients within } \\
\text { scope of physical therapy } \\
\text { practice } \\
\square \text { Follows state licensure } \\
\text { regulations } \\
\square \text { Abides by APTA Code of } \\
\text { Ethics } \\
\square \text { Keeps the patient/client as } \\
\text { the priority } \\
\square \text { Demonstrates accountability } \\
\text { for professional decisions } \\
\square \text { Collaborates with other } \\
\text { health care professionals in } \\
\text { decision-making } \\
\square \text { Directs patients/clients to } \\
\text { other health care professionals } \\
\text { when needed } \\
\square \text { Values the professional } \\
\text { organization } \\
\square \text { Serves as a positive } \\
\text { professional role model }\end{array}$ & $\begin{array}{l}\text { Activities to Achieve the } \\
\text { Goal: }\end{array}$ \\
\hline For Mentor Only & $\begin{array}{l}\text { Pre-Professional Phase: } \\
\square \text { Developing } \\
\square \text { Achieved }\end{array}$ & $\begin{array}{l}\text { Professional Phase: } \\
\square \text { Developing } \\
\square \text { Achieved }\end{array}$ & \\
\hline \multicolumn{4}{|l|}{ Mentor Comments: } \\
\hline
\end{tabular}




\begin{tabular}{|c|c|c|c|}
\hline Generic Ability & $\begin{array}{c}\text { Pre-Professional Phase } \\
\text { Descriptors }\end{array}$ & $\begin{array}{l}\text { Professional Phase } \\
\text { Descriptors }\end{array}$ & Plan for Development \\
\hline $\begin{array}{l}\text { 2. Critical Thinking \& } \\
\text { Problem Solving } \\
\text { The ability to question, think } \\
\text { logically, and define the } \\
\text { scope of a problem. The } \\
\text { individual identifies, gathers, } \\
\text { and analyzes relevant } \\
\text { information to develop } \\
\text { solutions and evaluate } \\
\text { outcomes. This process } \\
\text { includes the ability to } \\
\text { recognize presumptions, } \\
\text { biases, and potential faults in } \\
\text { logic. }\end{array}$ & $\begin{array}{l}\square \text { Describes scientific } \\
\text { method } \\
\square \text { Considers available } \\
\text { information with assistance } \\
\square \text { Raises relevant } \\
\text { questions } \\
\square \text { Describes problem } \\
\text { areas } \\
\square \text { Prioritizes problems } \\
\text { areas } \\
\square \text { Identifies multiple } \\
\text { contributors to problems } \\
\square \text { Considers multiple } \\
\text { solutions } \\
\square \text { Selects potential } \\
\text { solutions } \\
\square \text { Implements solutions } \\
\text { with assistance } \\
\square \text { Evaluates the chosen } \\
\text { solutions }\end{array}$ & $\begin{array}{l}\square \text { Considers consequences } \\
\text { of possible solutions before } \\
\text { acting } \\
\square \text { Values others' } \\
\text { approaches to problem } \\
\text { solving } \\
\square \text { Implements solutions } \\
\text { independently } \\
\square \text { Evaluates outcomes } \\
\square \text { Updates solutions to } \\
\text { problems based on new } \\
\text { knowledge } \\
\square \text { Demonstrates willingness } \\
\text { to examine contradictory } \\
\text { ideas } \\
\square \text { Formulates new ideas } \\
\square \text { Seeks alternative ideas } \\
\square \text { Critiques hypotheses and } \\
\text { ideas } \\
\square \text { Justifies solutions } \\
\text { selected } \\
\square \text { Critiques the results of } \\
\text { scientific literature } \\
\square \text { Considers available } \\
\text { information independently } \\
\square \text { Recognizes "holes" in } \\
\text { knowledge base }\end{array}$ & $\begin{array}{l}\text { Goal } \\
\text { (includes time } \\
\text { frame): }\end{array}$ \\
\hline For Mentor Only & $\begin{array}{l}\text { Pre-Professional Phase: } \\
\begin{array}{l}\square \text { Developing } \\
\square \text { Achieved }\end{array}\end{array}$ & $\begin{array}{l}\text { Professional Phase: } \\
\begin{array}{|l}\square \text { Developing } \\
\square \text { Achieved }\end{array}\end{array}$ & \\
\hline \multicolumn{4}{|l|}{ Mentor Comments: } \\
\hline
\end{tabular}




\begin{tabular}{|c|c|c|c|}
\hline Generic Ability & $\begin{array}{c}\text { Pre-Professional } \\
\text { Phase } \\
\text { Descriptors }\end{array}$ & $\begin{array}{l}\text { Professional Phase } \\
\text { Descriptors }\end{array}$ & Plan for Development \\
\hline $\begin{array}{l}\text { 3. Commitment to } \\
\text { Learning and Use of } \\
\text { Constructive Feedback } \\
\text { The ability to self-assess, } \\
\text { self-correct, and self- } \\
\text { direct; to identify needs } \\
\text { and sources of learning; } \\
\text { to seek out and } \\
\text { effectively use feedback; } \\
\text { to continually seek new } \\
\text { knowledge and } \\
\text { understanding. }\end{array}$ & $\begin{array}{l}\square \text { Attends class } \\
\text { consistently } \\
\square \text { Demonstrates a } \\
\text { positive attitude } \\
\text { (motivation) toward } \\
\text { learning } \\
\square \text { Shows evidence of } \\
\text { preparation prior to } \\
\text { class } \\
\square \text { Identifies need for } \\
\text { further information } \\
\square \text { Formulates and } \\
\text { asks appropriate } \\
\text { questions } \\
\square \text { Identifies and uses } \\
\text { appropriate resources } \\
\square \text { Offers own thoughts } \\
\text { and ideas } \\
\square \text { Receptive to } \\
\text { feedback } \\
\square \text { Uses feedback as a } \\
\text { stimulus for growth } \\
\square \text { Demonstrates } \\
\text { realistic self-evaluation } \\
\square \text { Sets personal goals } \\
\text { and plan of action with } \\
\text { assistance }\end{array}$ & $\begin{array}{l}\square \text { Seeks feedback } \\
\square \text { Demonstrates a positive } \\
\text { attitude toward feedback } \\
\square \text { Develops and } \\
\text { implements a plan of action } \\
\text { in response to feedback } \\
\square \text { Analyzes and } \\
\text { subdivides large questions } \\
\text { into components } \\
\square \text { Prioritizes information } \\
\text { needs } \\
\square \text { Uses professional } \\
\text { literature to identify limits of } \\
\text { practice } \\
\square \text { Evaluates own lab and } \\
\text { clinical performance } \\
\text { accurately and honestly } \\
\square \text { Sets personal and } \\
\text { professional goals } \\
\text { independently } \\
\square \text { Seeks opportunities to } \\
\text { expand knowledge } \\
\square \text { Applies new information } \\
\text { and re-evaluates } \\
\text { performance } \\
\square \text { Shares knowledge } \\
\text { through in-services, } \\
\text { research or case studies }\end{array}$ & $\begin{array}{l}\text { Activities to Achieve } \\
\text { the Goal: }\end{array}$ \\
\hline For Mentor Only & $\begin{array}{l}\text { Pre-Professional } \\
\text { Phase: } \\
\square \text { Developing } \\
\square \text { Achieved }\end{array}$ & $\begin{array}{l}\text { Professional Phase: } \\
\square \text { Developing } \\
\square \text { Achieved }\end{array}$ & \\
\hline \multicolumn{4}{|l|}{ Mentor Comments: } \\
\hline
\end{tabular}




\begin{tabular}{|c|c|c|c|}
\hline Generic Ability & $\begin{array}{l}\text { Pre-Professional } \\
\text { Phase } \\
\text { Descriptors }\end{array}$ & $\begin{array}{l}\text { Professional Phase } \\
\text { Descriptors }\end{array}$ & Plan for Development \\
\hline $\begin{array}{l}\text { 4. Communication and } \\
\text { Interpersonal Skills } \\
\text { The ability to interact and } \\
\text { communicate effectively } \\
\text { (speaking, body language, } \\
\text { reading, writing, listening) } \\
\text { with patients, families, } \\
\text { colleagues, health care } \\
\text { providers, and the } \\
\text { community in a culturally } \\
\text { competent manner. }\end{array}$ & $\begin{array}{l}\square \text { Writes legibly } \\
\square \text { Uses correct English } \\
\text { grammar and spelling in } \\
\text { written and verbal } \\
\text { communication } \\
\square \text { Uses communication } \\
\text { technology effectively } \\
\square \text { Respects cultural and } \\
\text { personal differences of } \\
\text { others } \\
\square \text { Listens carefully to } \\
\text { others } \\
\square \text { Uses appropriate eye } \\
\text { contact } \\
\square \text { Recognizes personal } \\
\text { biases } \\
\square \text { Communicates with } \\
\text { others in a respectful } \\
\text { and sensitive manner } \\
\square \text { Maintains privacy of } \\
\text { personal conversations } \\
\square \text { Articulates ideas } \\
\square \text { Asks clarifying } \\
\text { questions } \\
\square \text { Recognizes impact of } \\
\text { non-verbal } \\
\text { communication } \\
\square \text { Modifies interactions } \\
\text { with peers, faculty, and } \\
\text { staff based on verbal } \\
\text { and non-verbal cues } \\
\square \text { Respects differences } \\
\text { in learning styles of } \\
\text { peers } \\
\square \text { Provides feedback to } \\
\text { others }\end{array}$ & $\begin{array}{l}\square \text { Maintains confidentiality } \\
\square \text { Uses non-verbal communication to } \\
\text { augment verbal message } \\
\square \text { Presents verbal or written message } \\
\text { with logical organization } \\
\square \text { Demonstrates interest in } \\
\text { patients/clients as individuals } \\
\square \text { Does not allow personal biases to } \\
\text { compromise patient/client care or } \\
\text { decision-making } \\
\square \text { Establishes trust with patients/clients } \\
\text { and healthcare professionals } \\
\square \text { Displays professional behaviors in all } \\
\text { interactions } \\
\square \text { Acts in a manner that is respectful of } \\
\text { others' level of knowledge and } \\
\text { experience } \\
\square \text { Uses active listening techniques: } \\
\text { restates, reflects \& clarifies message } \\
\square \text { Selects and modifies communication } \\
\text { to meet the needs of different audiences } \\
\square \text { Composes patient/client notes clearly } \\
\text { and concisely } \\
\square \text { Respects and accommodates } \\
\text { differences in learning styles } \\
\square \text { Motivates others } \\
\square \text { Approaches others to discuss } \\
\text { differences in opinion } \\
\square \text { Demonstrates sensitivity when giving } \\
\text { and responding to feedback } \\
\square \text { Modifies interactions with } \\
\text { patients/clients, families, and others } \\
\text { based on verbal and non-verbal cues } \\
\square \text { Addresses health literacy* needs of } \\
\text { patients/clients } \\
\square \text { States clearly and concisely the } \\
\text { rationale for professional decision } \\
\text { making } \\
\square \text { Respects the role of support staff } \\
\square \text { Works effectively with challenging } \\
\text { patients/clients } \\
\square \text { Talks about difficult issues with } \\
\text { sensitivity and objectivity } \\
\square \text { Responds effectively to unexpected } \\
\text { experiences } \\
\square \text { Respects and interacts effectively } \\
\text { with the wide array of healthcare } \\
\text { professionals }\end{array}$ & $\begin{array}{l}\text { Goal } \\
\text { (Includes time } \\
\text { frame): }\end{array}$ \\
\hline \multicolumn{4}{|c|}{$\begin{array}{l}\text { *Health literacy is the degree to which the individual has the capacity to obtain, process, and to understand basic health information and } \\
\text { services needed to make appropriate health decisions }\end{array}$} \\
\hline For Mentor Only & $\begin{array}{l}\text { Pre-Professional Phase: } \\
\square \text { Developing } \\
\square \text { Achieved }\end{array}$ & $\begin{array}{l}\text { Professional Phase: } \\
\square \text { Developing } \\
\square \text { Achieved }\end{array}$ & \\
\hline \multicolumn{4}{|l|}{ Mentor Comments: } \\
\hline
\end{tabular}

(c) The Internet Journal of Allied Health Sciences and Practice, 2015 


\begin{tabular}{|c|c|c|c|}
\hline Generic Ability & $\begin{array}{c}\text { Pre-Professional Phase } \\
\text { Descriptors }\end{array}$ & $\begin{array}{c}\text { Professional Phase } \\
\text { Descriptors }\end{array}$ & Plan for Development \\
\hline $\begin{array}{l}\text { 5. Effective Use of } \\
\text { Time and } \\
\text { Resources } \\
\text { The ability to obtain a } \\
\text { maximum benefit } \\
\text { from a minimum } \\
\text { investment of time } \\
\text { and resources. }\end{array}$ & $\begin{array}{l}\square \text { Keeps personal time } \\
\text { schedule } \\
\square \text { Demonstrates } \\
\text { punctuality and attendance } \\
\text { for meetings, classes, and } \\
\text { labs } \\
\square \text { Stays on task } \\
\square \text { Uses available academic } \\
\text { and other resources } \\
\square \text { Follows through with } \\
\text { commitments } \\
\square \text { Self-identifies time } \\
\text { wasting behaviors } \\
\square \text { Appropriately prioritizes } \\
\text { tasks/activities } \\
\square \text { Demonstrates the ability } \\
\text { to say "no" } \\
\square \text { Realistically assess the } \\
\text { time needed to meet } \\
\text { personal goals with } \\
\text { assistance } \\
\square \text { Manages multiple } \\
\text { personal and academic } \\
\text { tasks effectively }\end{array}$ & $\begin{array}{l}\square \text { Reassesses priorities on a } \\
\text { regular basis } \\
\square \text { Uses available resources } \\
\text { efficiently } \\
\square \text { Realistically assesses the } \\
\text { time needed to meet personal } \\
\text { and professional goals } \\
\text { independently } \\
\square \text { Manages multiple } \\
\text { professional tasks effectively } \\
\square \text { Demonstrates flexibility in } \\
\text { scheduling in a clinical setting } \\
\square \text { Maximizes time efficiency by } \\
\text { delegating clinical tasks } \\
\text { appropriately } \\
\square \text { Uses scheduled time with } \\
\text { patients/ clients efficiently } \\
\square \text { Considers patient/client, } \\
\text { clinic, and third party resources } \\
\text { when planning interventions } \\
\square \text { Realistically assesses the } \\
\text { time needed to achieve } \\
\text { patient/client goals }\end{array}$ & $\begin{array}{l}\text { Goal (includes } \\
\text { time frame): } \\
\text { Activities to } \\
\text { Achieve the Goal: }\end{array}$ \\
\hline For Mentor Only & $\begin{array}{l}\text { Pre-Professional Phase: } \\
\square \text { Developing } \\
\square \text { Achieved }\end{array}$ & $\begin{array}{l}\text { Professional Phase: } \\
\square \text { Developing } \\
\square \text { Achieved }\end{array}$ & \\
\hline \multicolumn{4}{|l|}{ Mentor Comments: } \\
\hline
\end{tabular}




\begin{tabular}{|c|c|c|c|}
\hline Generic Ability & $\begin{array}{c}\text { Pre-Professional } \\
\text { Phase } \\
\text { Descriptors }\end{array}$ & $\begin{array}{c}\text { Professional Phase } \\
\text { Descriptors }\end{array}$ & Plan for Development \\
\hline $\begin{array}{l}\text { 6. Stress } \\
\text { Management } \\
\text { The ability to identify } \\
\text { sources of stress } \\
\text { and to develop } \\
\text { effective coping } \\
\text { behaviors. }\end{array}$ & $\begin{array}{l}\square \text { Recognizes the signs } \\
\text { of stress or problems in } \\
\text { others } \\
\square \text { Recognizes own } \\
\text { stressors or problems } \\
\square \text { Seeks assistance as } \\
\text { needed } \\
\square \text { Establishes } \\
\text { appropriate outlets to } \\
\text { cope with stressors } \\
\square \text { Maintains balance } \\
\text { among social, } \\
\text { academic, spiritual, and } \\
\text { work-related activities } \\
\square \text { Demonstrates } \\
\text { appropriate affective } \\
\text { responses during most } \\
\text { situations e.g., tests, } \\
\text { personal communication }\end{array}$ & $\begin{array}{l}\square \text { Demonstrates } \\
\text { appropriate affective } \\
\text { responses in all situations } \\
\square \text { Responds calmly to } \\
\text { urgent situations } \\
\square \text { Recognizes } \\
\text { inconsistencies in the } \\
\text { healthcare environment and } \\
\text { develops a plan to cope } \\
\text { with the inconsistencies } \\
\square \text { Maintains balance } \\
\text { between personal and } \\
\text { professional life } \\
\square \text { Accepts when problems } \\
\text { are unsolvable }\end{array}$ & $\begin{array}{l}\text { Goal (includes time } \\
\text { frame): } \\
\text { Activities to Achieve the } \\
\text { Goal: }\end{array}$ \\
\hline For Mentor Only & $\begin{array}{l}\text { Pre-Professional Phase: } \\
\square \text { Developing } \\
\square \text { Achieved }\end{array}$ & $\begin{array}{l}\text { Professional Phase: } \\
\square \text { Developing } \\
\square \text { Achieved }\end{array}$ & \\
\hline \multicolumn{4}{|l|}{ Mentor Comments: } \\
\hline
\end{tabular}


Appendix B

Saint Louis University

Doisy College of Health Sciences

Program in Physical Therapy

\section{POLICY AND PROCEDURE CONCERNING PROFESSIONAL BEHAVIOR}

Physical Therapy is a human service profession. One of its central tenets is the value of human dignity. This value is reflected in conduct that demonstrates sensitivity to the physical and psychological well-being of others and honesty in all endeavors. The Program in Physical Therapy endorses the philosophy and behaviors embodied in the Mission Statement of Saint Louis University, the Code of Ethics and Core Values of the American Physical Therapy Association, and the Generic Abilities as defined by the Program. The Program expectations of the student's professional behaviors are based on these documents and the University, College, and Program policies and procedures.

No code of ethics or professional standards can address every possible scenario that may arise in the future. However, in the Student/Professional Development course series, students are educated in acceptable professional behaviors and as such, are expected to conduct themselves in a manner that is consistent with the following minimal standards:

1. develop a knowledge of self

2. demonstrate good judgment

3. conduct themselves in an ethical manner including but not limited to:

a. maintenance of confidentiality

b. honesty concerning personal, academic, and medical information

4. commit to fulfilling professional responsibilities

5. demonstrate respect for self and others including but not limited to:

a. provisions for the physical safety of others

b. respect for the psychological welfare of others

The Program in Physical Therapy reserves the right to pursue disciplinary action for any behavior, regardless of where it occurred, that violates these standards. Disciplinary actions include:

1. No sanction

2. Professional Behavior Warning

3. Professional Behavior Probation

4. Dismissal

It is the responsibility of the faculty member who identifies or observes a behavior that is not congruent with program standards or is notified by a clinical instructor of said behavior to meet with the student to discuss the level of sanction.

\section{No Sanction:}

Definition: No sanction is issued in situations in which the faculty member uses the professional behavior advisement process to inform the student about his or her unacceptable behavior. A pattern of unacceptable behaviors will result in a Professional Behavior Warning.

\section{Process:}

1. Meet with the student to discuss said breach of professional behavior and possible strategies to improve behavior.

2. Document meeting on the Professional Behavior Advisement Form.

3. Secure signatures from student and faculty on the Professional Behavior Advisement Form.

4. Allow student to respond in writing to clarify his or her perception of the situation. This response will be attached to the Professional Behavior Advisement Form.

5. Provide an electronic or hard copy of the Professional Behavior Advisement Form to the student's faculty mentor.

6. Place a hard copy of the Professional Behavior Advisement Form in the student's permanent file. 
7. Faculty mentor is responsible for monitoring the number of Professional Behavior Advisement Forms resulting in "No Sanction". Multiple "No Sanctions" may result in a Professional Behavior Warning being issued by the mentor.

8. All Professional Behavior Advisement Forms will be removed from the student's permanent file upon graduation, withdrawal, or dismissal from the program.

\section{Professional Behavior Warning:}

Definition: A Professional Behavior Warning is a sanction given to a student who demonstrates multiple breaches of professional behaviors identified in the above mentioned documents or a single serious action. A Professional Behavior Warning can be issued by any faculty member. If a faculty mentor receives multiple notifications of unacceptable student behaviors, the faculty mentor will issue a Professional Behavior Warning.

\section{Process:}

1. Meet with the student to discuss said breach of professional behavior and possible strategies to improve behavior.

2. Document meeting on the Professional Behavior Advisement Form.

3. Secure signatures from student and faculty on the Professional Behavior Advisement Form.

4. Allow student to respond in writing to the sanction to clarify his or her perception of the situation. This response will be attached to the Professional Behavior Advisement Form.

5. Provide an electronic or hard copy of the Professional Behavior Advisement Form to the student's faculty mentor.

6. Place a hard copy of the Professional Behavior Advisement Form in the student's permanent file.

7. Faculty mentor is responsible for monitoring the number of Professional Behavior Warnings received by a student.

8. All documentation regarding Professional Behavior Warning will be removed from the student's permanent file upon graduation, withdrawal, or dismissal from the program.

\section{Professional Behavior Probation:}

Definition: If a student receives a second Professional Behavior Warning, the student will be placed on Professional Behavior Probation. If the student receives one warning of a nature which warrants probation in the professional judgment of the student's faculty mentor, the Program Assistant Director, and the Program Director, the student will be placed on Professional Behavior Probation. Professional Behavior Probation entails the completion of certain specified activities and/or the ability to demonstrate appropriate change in the observed behaviors as designated in a written contract and determined by recommendations from concerned faculty.

\section{Process:}

1. Student will be notified by his or her faculty mentor of probationary status using traceable mail.

2. Program Director will follow-up with a letter confirming the probationary status.

3. Student will be required to return a signed confirmation of this notification.

4. Appropriate faculty member/mentor and student will discuss possible strategies to improve professional behaviors.

5. Appropriate faculty member/mentor will develop a written contract with the student for remediation.

6. Any subsequent meetings between the faculty member/mentor and the student will be documented.

7. Student will be removed from Professional Behavior Probation after one full enrolled semester free of professional behavior breaches.

8. Once a student has been removed from Professional Behavior Probation, a subsequent Professional Behavior Warning will warrant Professional Behavior Probation.

9. All documentation regarding Professional Behavior Probation will be removed from the student's permanent file upon graduation, withdrawal, or dismissal from the program.

\section{Professional Behavior Dismissal:}

Definition: A student is subject to program dismissal for professional behavior issues due to the following conditions:

1. In the judgment of the student's faculty mentor, the assistant Program Director, and the Program Director, the student does not demonstrate satisfactory change by the end of the Professional Behavior Probation.

2. The student receives a Professional Behavior Warning while on Professional Behavior Probation. 
3. In the judgment of the student's faculty mentor, the Program Assistant Director, and the Program Director, the student demonstrates a behavior that is of a serious nature including, but not limited to academic misconduct or intent to cause physical or emotional harm to another individual.

Process:

1. When the student is dismissed the student will be notified by the Program Director using traceable mail.

2. The student will be required to return a signed confirmation of this notification.

\section{Appeal Process:}

Definition: The student has the right to appeal dismissal from the Physical Therapy program.

\section{Process:}

1. Program Appeal: A full description of the appeal process is available in the Progressions Committee Procedures document. If the student chooses to appeal the professional behavior dismissal, the process includes:

a. The appeal request must be made in writing to the Progression Committee Chairperson within seven business days following program dismissal notification.

b. The appeal gives the student the opportunity to explain circumstances or conditions which adversely impacted his or her behavior.

c. The appeal is heard by the Program in Physical Therapy Progressions Committee. The Committee makes a decision regarding the student's appeal and communicates it to the Program Director.

d. The Program Director reviews the decision regarding the student's appeal and communicates this decision to the student as stated in the Progressions Committee Procedures document.

2. Doisy College of Health Sciences Academic Integrity Policy Appeal: The student can file a grievance with the Dean of the Doisy College of Health Sciences on completion of all program processes on the following grounds:

a. Program policies were not followed

b. The student was not informed of the program policies

c. No appeal was allowed

d. Procedural infractions occurred

If the student believes his or her case meets these requirements, the process is initiated by sending a formal written letter of appeal to the Dean within 14 working days of receiving the decision from the Program. The letter of appeal should review the case and, at minimum, include the following points:

a. A description of the complaint

b. The relationship of the grievance to program policies

c. Program channels already pursued to resolve the grievance

d. Results of discussions/actions within the program

e. Any pertinent documentation

f. A summary of the resolution desired by the student

Revised 12/2004

Revised 1/2005

Revised 8/2007 


\section{Appendix C \\ Saint Louis University \\ Doisy College of Health Sciences \\ Program in Physical Therapy \\ Professional Behavior Advisement Form}

Student Name:

Date of Meeting:

Class Year: [ ] Freshman [ ] Sophomore [ ] Junior [ ] Senior [ ] PY I [ ] PYII, [ ] Cl

Faculty Name:

[ ] Mentor [ ] Course Coordinator [ ] Faculty ( ) Cl Team

Level of Sanction: [ ] No Sanction [ ] Professional Behavior Warning \#1 \#2

[ ] Professional Behavior Probation [ ] $\overline{\text { Dismissal }}$

Generic Abilities: [ ] Responsibility and Professionalism

[ ] Critical Thinking and Problem Solving

[ ] Commitment to Learning and use of Constructive Feedback

[ ] Communication and Interpersonal Skills

[ ] Effective Use of Time and Resources

[ ] Stress Management

Description of Unacceptable Behavior(s):

Student Perception/Response:

Expected Behavior Change and Possible Strategies:

Faculty Signature:

Date:

Student Signature: Date: 